\title{
Urgensi Wakaf Produktif Dalam Pembangunan Ekonomi Masyarakat
}

\author{
Dewi Sri Indriati (dewisrisri99@ yahoo.co.id) \\ Balai Diklat Kota Manado, Sulawesi Utara, Indonesia
}

\begin{abstract}
Strategies that can be developed to empower this productive zakat, ranging from legal products to building networks in the form of productive investment partnerships. One is money endowments that can open up unique opportunities to create investments to provide religious services, educational services, and social services. Nazhir has an important role in managing endowments property in accordance with what is desired by the endowments and can be benefited by the community then Nazhir must have programs work both short-term programs and long-term programs. In order to develop endowments productively, the government established Badan Wakaf Indonesia (BWI) which has the purpose to coordinate with Nazhir and the development of national and international endowments management. The medium and long-term program is to develop existing Nazhir institutions to be more credible (professional and trustworthy) so the institutions should be directed, nurtured and given stimulus (stimulus) so that the endowments property can be developed productively.

Keynotes: ProductiveEndowments, Social, Economic
\end{abstract}

\begin{abstract}
ABSTRAK
Strategi yang dapat dikembangkan untuk memberdayakan zakat produktif ini, mulai dari produk hukumnya sampai pada membangun jaringan dalam bentuk kemitraan investasi produktif.Salah satunya adalah wakaf uang yang dapat membuka peluang yang unik untuk menciptakan investasi guna memberikan pelayanan keagamaan, layanan pendidikan, dan layanan sosial.Nazhir mempunyai peranan penting dalam mengelola harta wakaf agar sesuai dengan apa yang diinginkan oleh wakif dan bisa dirasakan manfaatnya oleh masyarakat maka Nazhir harus mempunyai program-program kerja baik program jangka pendek maupun program jangka panjang.Dalam rangka mengembangkan wakaf secara produktif, maka pemerintah membentuk Badan Wakaf Indonesia (BWI) yang mempunyai tujuan untuk
\end{abstract}


menyelenggarakan koordinasi dengan Nazhir dan pembinaan manegemen wakaf secara nasional dan internasional. Program jangka menengah dan panjang yaitu mengembangkan lembaga-lembaga Nazhir yang sudah ada agar lebih kredibel (professional dan amanah) maka lembaga-lembaga tersebut harus diarahkan, dibina dan diberikan stimulus(rangsangan) agar harta wakaf tersebut dapat dikembangkan secara produktif.

Kata Kunci: Wakaf Produktif, Sosial, Ekonomi 


\section{PENDAHULUAN}

Undang-Undang Republik Indonesia No. 41 tahun 2004 tentang Wakaf mencakup harta tidak bergerak maupun yang bergerak, termasuk wakaf uang yang penggunaannya sangat luas, tidak terbatas untuk pendirian tempat ibadah dan sosial keagamaan (UU. Nomor: 41 Tahun 2004). Formulasi hukum yang demikian, jelas suatu perubahan yang sangat revolusioner dan jika dapat direalisasikan akan memiliki akibat yang berlipat ganda atau multiplier effect, terutama dalam kaitannya dengan pemberdayaan ekonomi umat Islam. Namun, usaha ke arah itu jelas bukan pekerjaan yang mudah.Umat Islam Indonesia selama ribuan tahun sudah terlanjur mengidentikkan wakaf dengan (dalam bentuk) tanah, dan benda bergerak yang sifatnya bendanya tahan lama.

Dengan demikian, Undang-Undang No. 41 tahun 2004 tentang Wakaf diproyeksikan sebagai sarana rekayasa sosial (social engineering), melakukan perubahan-perubahan pemikiran, sikap dan perilaku umat Islam agar searah dengan semangat UU tersebut.Salah satu regulasi baru dalam Undang-Undang Wakaf tersebut adalah Wakaf Uang. Makalah ini akan mencoba membahas wakaf produktif tersebut dalam perspektif ekonomi Islam dan bagaimana prospeknya dalam pemberdayaan ekonomi umat Islam.

Di tengah problem sosial masyarakat Indonesia dan tuntutan akan kesejahteraan ekonomi akhir-akhir ini, keberadaan wakaf uang menjadi sangat strategis. Disamping sebagai salah satu aspek ajaran Islam yang berdimensi spiritual, wakaf uang juga merupakan ajaran yang menekankan pentingnya kesejahteraan ekonomi (dimensi sosial) dan kesejahteraan umat (Direktorat Pemberdayaan Wakaf dan Direktorat Jenderal Bimbingan Masyarakat Islam, 2008:1).

Namun istilah wakaf uang belum begitu familiar di tengah masyarakat Indonesia, ini bisa dilihat dari pemahaman masyarakat Indonesia yang memandang wakaf hanya sebatas pada pemberian berbentuk barang tidak bergerak, seperti tanah dan bangunan yang diperuntukkan untuk tempat ibadah, kuburan, pondok pesantren, rumah yatim piatu dan pendidikan semata. Pemanfaatan benda wakaf masih berkisar pada hal-hal yang bersifat fisik, sehingga tidak memberikan dampak ekonomi secara signifikan terhadap kesejahteraan masyarakat. Banyaknya harta benda wakaf yang ada di masyarakat Indonesia belum mampu 
mengatasi masalah kemiskinan.Hal ini disebabkan karena wakaf tersebut belum dapat dikelola secara maksimal, sementara penduduk miskin dari tahun ke tahun semakin meningkat baik di perkotaan maupun di pedesaan. Di bawah ini merupakan penduduk miskin di Indonesia baik wilayah perkotaan maupun pedesaan:

Grafik 1: Pendidik Miskin Perkotaan dan Pedesaan Maret 2015-Maretn 2016 di Indonesia

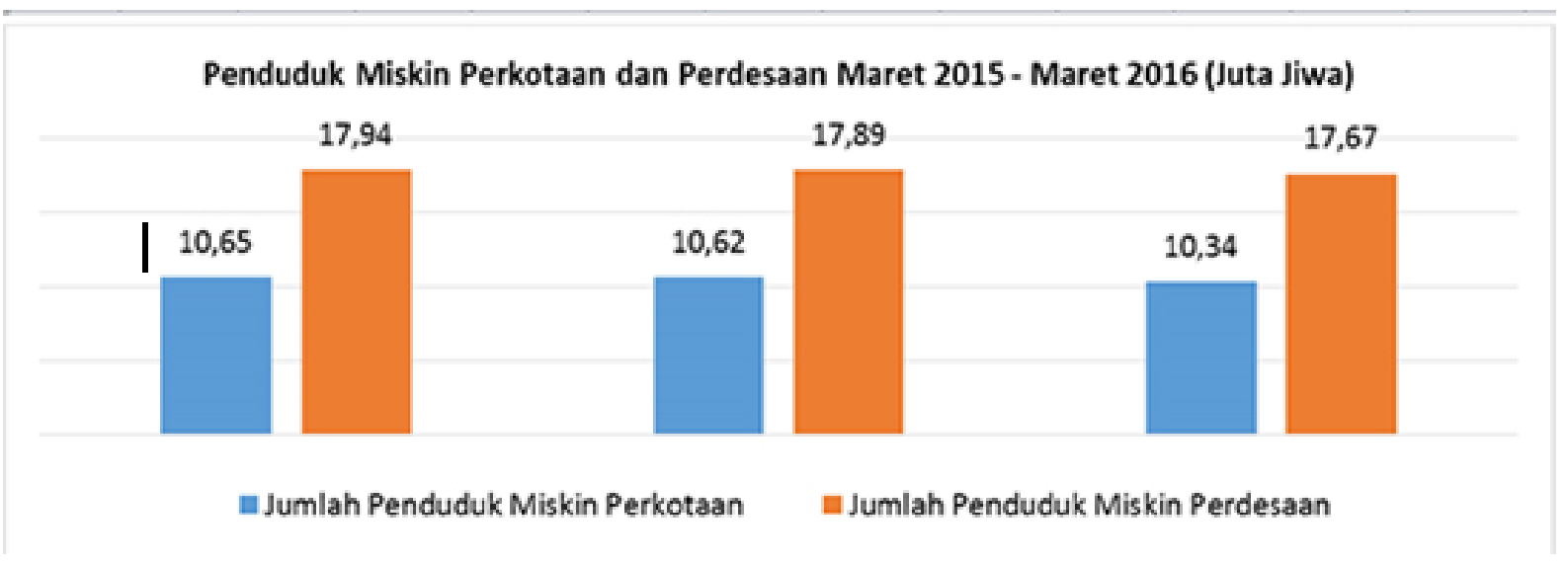

Sumber: Badan Pusat Statistik (BPS)

Profil Kemiskinan di Indonesia Maret 2016 diterbitkan Badan Pusat Statistik (BPS) pada tanggal 18 Juli 2016. Menurut BPS, jumlah penduduk miskin-penduduk dengan pengeluaran per kapita per bulan di bawah garis kemiskinan-pada Maret 2016 di Indonesia mencapai 28,01 juta jiwa atau sebesar 10,86 persen dari total jumlah penduduk Indonesia. Walaupun dari sisi jumlah kemiskinan di pedesaan menurun, namun secara persentase penduduk miskin meningkat. Pada bulan Maret 2015 persentase penduduk miskin pedesaan sebesar 14,21 persen, lalu turun padaSeptember 2015 menjadi 14,09 persen kemudian naik 0,02 persen di bulan Maret 2016 menjadi 14,11 persen. Bila mengacu data Nilai Tukar Petani (NTP) yang terus menurun dari 102,55 pada Januari 2016 menjadi 101,47 pada Juni 2016 maka wajar jika persentase kemiskinan di perdesaan meningkat, karena usaha pertanian menurun(Badan Pusat Statistik (BPS), 2017:112).

Jika kita lihat bahwa tujuan Negara Kesatuan Republik Indonesia sebagaimana diamanatkan dalam Pembukaan Undang-Undang Dasar Negara Republik Indonesia Tahun 1945 antara lain adalah memajukan kesejahteraan umum (Redaksi Tamita Utama. UUD 45 dan Amandemen I-IV, 2008:1). Untuk mencapai tujuan tersebut, perlu menggali dan 
mengembangkan potensi yang terdapat dalam pranata keagamaan yang memiliki manfaat ekonomis. Salah satu langkah strategis untuk meningkatkan kesejahteraan umum, perlu meningkatkan peran wakaf sebagai pranata keagamaan yang tidak hanya bertujuan menyediakan berbagai sarana ibadah dan sosial, tetapi juga memiliki kekuatan ekonomi yang berpotensi, antara lain untuk memajukan kesejahteraan umum, sehingga perlu dikembangkan pemanfaatannya sesuai dengan prinsip syariah.

Jadi melalui kesempatan ini akan dikaji sejauhmanaperan wakaf produktif dalam membantu program-program pemerintah berkaitan dengan peningkatan kesejahteraan masyarakat. Secara umum wakaf adalah suatu perbuatan hukum seseorang atau badan hukum dengan memisahkan sebagian dari harta kekayaannya yang berupa tanah milik dan melembagakannya selama-lamanya untuk kepentingan peribadatan atau kepentingan umum lainnya. Sedikit berbeda dengan pengertian di atas, yaitu pengertian wakaf sebagaimana dicantumkan dalam Instruksi Presiden No. 1 tahun 1991, yang tidak menyebutkan harta kekayaan yang berupa tanah (wakaf adalah perbuatan hukum seseorang atau sekelompok orang atau badan hukum yang memisahkan sebagian harta miliknya dan melembagakannya untuk selama-lamanya guna kepentingan ibadat atau keperluan umum lainnya sesuai dengan ajaran Islam). Jadi esensi perwakafan adalah "Menahan suatu benda sehingga memungkinkan untuk diambil manfaatnya dengan masih tetap zat (materi) bendanya" (Eddy Khairani, 2013:18).

Dalam penulisan jurnal ini, fokusnya adalah terkait dengan wakaf produktif yang merupakan salah satu faktor penting untuk dapat menunjang pembangunan ekonomi masyarakat, karena langsung bersentuhan dengan masyarakat.

\section{STRATA SOSIAL MASYARAKAT}

Dalam kehidupan masyarakat, pada hakekatnya tak lebih dari pertentangan kelas sosial, yakni pertentangan antar masyarakat kelas dominan (borjuis) dan masyarakat kelas subordinat (proletar). Pertentangan kelas sendiri dapat dimanifestasikan sebagai suatu usaha yang ditempuh oleh kaum proletar dalam usahanya guna menciptakan kesejahteraan bagi masyarakat tanpa tebang pilih dan menghapuskan kelas-kelas sosial dalam 
masyarkat.Pertentangan kelas ini terjadi bukan tanpa sebab, jika kita merujuk pada perkembangan sejarah manusia bahwasanya pertentangan kelas ini telah dimulai sejak era masyarakat primitif,kuno,feodal sampai dengan masyarakat post-modernisme.

Sumberdaya alam yang jumlahnya tebatas dan berubahnya pola konsumsi masyarakat menjadi salah satu pendorong utama munculnya kelas-kelas sosial. Jika dahulu masyarakat hanya mengkonsumsi barang sesuai dengan apa yang ia butuhkan namun berbeda dengan yang terjadi sekarang ini, di era moderinisasi, masyarakat mengkonsumsi barang bukan hanya melihat dari segi nilai guna barang tersebut, namun lebih kepada prestise yang terdapat pada barang tersebut. Berbicara ke-2 kelas diatas yakni kelas dominan dan subordinat, kita akan membahasnya secara lebih terperinci:

\section{KELAS DOMINAN}

Kelas dominan atau sering disebut masyarakat borjouis dapat juga disebut kelas masyarakat yang memiliki berbagai faktor- faktor produksi (Tanah, SDA, Modal, alat produksi, dsb), masyarakat kelas dominan ini biasanya berjumlah lebih sedikit dibanding dengan kelas masyarakat subordinat.

\section{KELAS SUBORDINAT}

Kelas Subordinat atau masyarakat proletar (kelas pekerja) yakni kelas masyarakat yang tidak memiliki faktor-faktor produksi, masyarakat kelas ini hanya melakukan kegiatan-kegiatan yang orientasinya memberikan nilai lebih kepada para pemegang faktor-faktor produksi, Kelas masyarakat ini jumlahnya lebih banyak jika dibanding dengan masyarakat borjuis.Pasca meletusnya peristiwa revolusi industri di Prancis pada abad ke-19, pertentangan kelas ini semakin begitu terasa dalam kehidupan sosial masyarakat.Revolusi industry yang dimulai di Prancis kian hari kian menjangkit ke seluruh Negara dibelahan dunia (AdiwarmanAzwar Karim, 2004:89).Abad tersebut merupakan babak baru pertentangan kelas dalam masyarakat yang tak dapat terelakan lagi, hal ini berimbas pada kian mantapnya pertentangan kelas sosial dalam kehidupan masyarakat. Jika kita mengacu pada hakikat manusia maka tidak menjadi sebuah pembenaran jika di dalam masyarakat terdapat sekat- 
sekat masyarakat menjadi kelas-kelas sosial, karena pada dasarnya semua manusia mempunyai kedudukan dan hak yang sama, yang menjadi pembeda hanya peran yang mereka lakoni dalam dunia yang paradoksi ini. Dan pada puncakanya pertentangan kelas dominan dan subordinat dari masa ke masa tak akan pernah usai, jika kita sebagai subyek dari kelas tersebut tak pernah sadar dimana kita akan memposisikan diri dalam ke-2 jenis kelas tersebut, sehingga untuk mencapai masyarakat tanpa kelas masih akan menjadi sebuah keniscayaan.

Namun secara realitas, disadari ataupun tidak ada orang-orang yang dipandang tinggi kedudukannya dan ada pula yang dipandang rendah kedudukannya.Dalam istilah sosiologi kedudukan seseorang dalam masyarakat disebut status atau kedudukan sosial (posisi seseorang dalam suatu pola hubungan sosial yang tertentu).Status merupakan unsur utama pembentukan strata sosial, karena status mengandung aspek struktural dan aspek fungsional.Aspek struktural adalah aspek yang menunjukkan adanya kedudukan-tinggi dan rendah dalam hubungan antar status.Aspek fungsional, yaitu aspek yang menunjukkan adanya hak-hak dan tanggung jawab yang harus dilaksanakan oleh penyandang status tersebut.

\section{DALIL WAKAF PRODUKTIF}

Secara umum tidak terdapat ayat al-Qur'an yang menerangkan konsep wakaf secara konkrit tekstual.Wakaf termasuk infaq fi sabilillah, maka dasar yang digunakan para ulama dalam menerangkan konsep wakaf ini didasarkan pada keumuman ayat-ayat al-Qur'an yang menjelaskan tentang infaq fi sabilillah. Di antara ayat-ayat tersebut antara lain: QS alBaqarah/2:267.

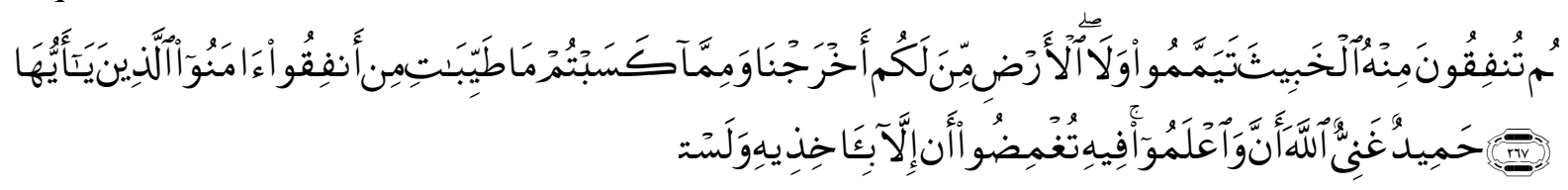

Terjemahnya:

Wahai orang-orang yang beriman! Infakkanlah sebagian dari hasil usahamu yang baik-baik dan sebagian dari apa yang Kami keluarkan dari bumi untukmu. Janganlah kamu memilih yang buruk untuk kamu keluarkan, padahal kamu sendiri tidak mau mengambilnya melainkan 
dengan memicingkan mata (enggan) terhadapnya.Dan ketahuilah bahwa Allah Mahakaya, Maha Terpuji (Kementerian Agama RI, 2012:56).

Ayat al-Qur'an selanjutnya, yaitu: QS Ali Imran/3:92

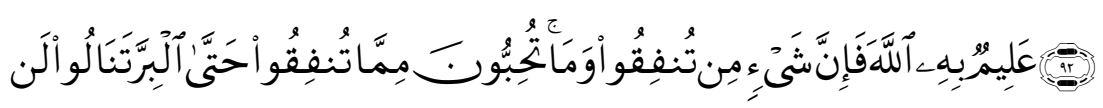

Terjemahnya:

Kamu tidak akan memperoleh kebajikan, sebelum kamu menginfakkan sebagian harta yang kamu cintai. Dan apa pun yang kamu infakkan, tentang hal itu sungguh, Allah Maha Mengetahui. (Kementerian Agama RI, 2012:77).

Hadits yang diriwayatkan oleh Muslim dari Ibnu Umar:

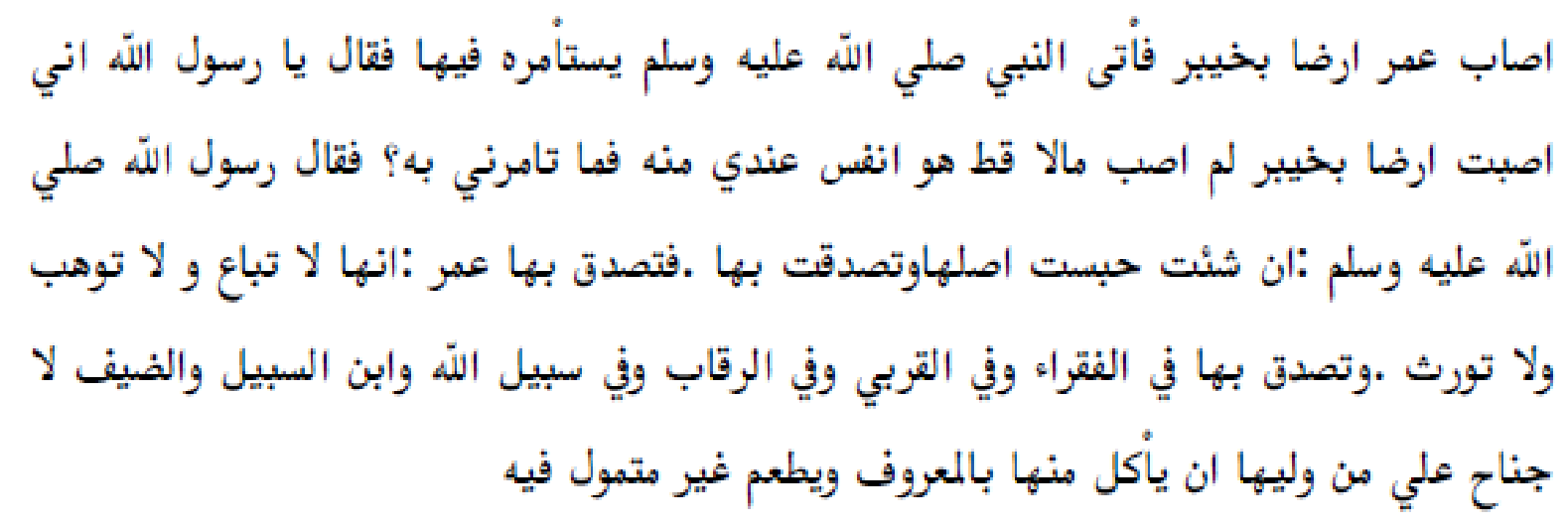

Artinya:

"Bahwa Umar bin al Khattab r.a. memperoleh tanah di Khaibar, lalu ia datang kepada Nabi saw.untuk meminta petunjuk mengenai tanah tersebut. Ia berkata, "Wahai Rasulullah saya memperoleh tanah di Khaibar yang belum pernah saya peroleh harta yang lebih baik bagiku melebihi tanah tersebut; apa perintah engkau kepadaku mengenainya? Nabi saw.menjawab: "Jika mau, kamu tahan pokoknya dan kamu sedekahkan hasilnya. Ibnu Umar berkata "Maka, Umar menyedekahkan tanah tersebut, dengan mensyaratkan bahwa tanah itu tidak dijual, tidak dihibahkan, dan tidak diwariskan.Ia menyedekahkan hasilnya kepada fuqara', kerabat, riqab, sabilillah, ibnu sabil, dan tamu. Tidak berdosa atas orang yang mengelolanya untuk memakan dari hasil itu secara ma'ruf dan memberi makan kepada orang lain tanpa 
menjadikannya sebagai harta hak milik" (M. Anwar Musaddad, 2014:http://www.wakafcenter.org).

Perilaku sejenis wakaf telah dikenal umat manusia sebelum Islam datang.Umat manusia terlepas dari agama dan kepercayaan yang mereka anut sesungguhnya telah mengenal beberapa bentuk praktik pendayagunaan harta benda, yang substansinya tidak jauh berbeda dengan wakaf dalam Islam.Hal ini disebabkan pada dasarnya, umat manusia sudah menyembah Tuhan melalui ritual keagamaan sesuai kepercayaan mereka.Hal inilah yang kemudian menjadi faktor pendorong bagi setiap umat beragama untuk mendirikan bangunan peribadatannya masing-masing (Aziz, Hamka Abdul, 2012:379).

Jika praktik wakaf telah dikenal sebelum Islam, maka yang membedakannyadengan wakaf dalam Islam adalah bahwa praktik wakaf yang diamalkan masyarakat 1jahiliyah dilakukan semata-mata hanya untuk mencari prestise (kebanggaan).Sedangkan dalam Islam wakaf bertujuan untuk mencari ridha Allah dan sebagai sarana mendekatkan diri kepadaNya.Dalam sejarah Islam, wakaf dikenal sejak masa Rasulullah saw.karena wakaf disyari'atkan pada tahun kedua Hijriyah. (Direktorat Pemberdayaan Wakaf dan Direktorat Jenderal Bimbingan Masyarakat Islam, 2008:4). Ada dua pendapat yang berkembang di kalangan ahli yurisprudensi Islam (fuqaha') tentang siapa yang pertama kali melaksanakan syariat wakaf. Menurut sebagian pendapat ulama mengatakan bahwa yang pertama kali melaksanakan wakaf adalah Rasulullah saw. yaitu wakaf tanah milik Nabi saw.untuk dibangun masjid. Sebagian ulama menyatakan bahwa yang pertama kali melaksanakan syari'at wakaf adalah Umar bin Khatab (M. Ali Hasan, 2003:112).Pendapat ini berdasarkan hadits yang diriwayatkan Ibnu Umar ra, sebagaimana telah dikemukakan di atas.

Praktek wakaf juga berkembang luas pada masa dinasti Umayyah dan dinasti Abbasiyah dan dinasti sesudahnya, banyak orang berduyun-duyun untuk melaksanakan wakaf, dan wakaf tidak hanya untuk orang-orang fakir dan miskin saja, tetapi wakaf menjadi modal untuk membangun lembaga pendidikan, membangun perpustakaan dan membayar gaji para stafnya, gaji para guru dan beasiswa untuk para siswa dan mahasiswa. Antusiasme masyarakat kepada pelaksanaan wakaf telah menarik perhatian negara untuk mengatur pengelolaan wakaf sebagai sektor untuk membangun solidaritas sosial dan ekonomi 
masyarakat (Direktorat Pemberdayaan Wakaf dan Direktorat Jenderal Bimbingan Masyarakat Islam, 2008:8).

\section{PROBLEMATIKA PERWAKAFAN DI INDONESIA}

Menurut M. Ichsan Amir Mujahid bahwa problematika perwakafan di Indonesia sebagaimana urarian dibawah ini (M.Ichsan Amir Mujahid, 2012 :, http://k2ichsan.blogspot.com/2012/06/strateg).

a. Kuatnya paham lama umat Islam dalam pengelolaan wakaf, seperti adanya anggapan bahwa wakaf itu milik ALLAH semata yang tidak boleh diubah/ganggu gugat. Atas pemahaman itu, banyak tokoh masyarakat atau umat Islam tidak merekomendasikan wakaf dikelola secara produktif. Selain itu, belum utuhnya pemahaman bahwa wakaf memiliki fungsi sosial yang lebih luas dan tidak terbatas pada ibadah mahdhah.

b. Kurangnya sosialisasi secara lebih luas terhadap paradigma baru untuk pengembangan wakaf secara produktif. Sosialisasi massif dengan memasukkan wakaf sebagai bagian dari instrumen pengembangan ekonomi umat menjadi aspek penting bagi pengembangan gagasan wakaf produktif. Dengan kurangnya pengetahuan masyarakat atas pentingnya pemberdayaan wakaf untuk kesejahteraan umum menjadi problem yang harus dipecahkan bersama.

c. Belum mempunyai persepsi yang sama, peran dan sinergi para pejabat teknis wakaf di daerah dengan para pihak terkait terhadap upaya pemerintah pusat dalam upaya pengembangan wakaf. Para pejabat teknis lebih banyak berkutat pada penanganan yang bersifat linier dibandingkan memasarkan gagasan strategis dalam pengembangan wakaf yang lebih berwawasan sosial.

d. Nazhir belum profesional sehingga wakaf belum dikelola secara optimal. Posisi Nazhir menempati peran sentral dalam mewujudkan tujuan wakaf yang ingin melestarikan manfaat wakaf. Profesionalisme nazhir di Indonesia masih tergolong lemah. Mayoritas dari mereka lebih karena faktor kepercayaan dari masyarakat, sementara kompetensi minimal sebagai pengelola wakaf secara produktif belum banyak dimiliki. 
e. Lemahnya kemitraan dan kerjasama antara stake holders wakaf untuk menjalin kekuatan internal umat Islam dalam mengelola dan mengembangkan wakaf secara produktif, sepeti organisasi massa Islam, kalangan intelektual, LSM, tokoh agama, termasuk aparat pemerintah. Kemitraan mereka lebih pada upaya-upaya yang masih bersifat artifisial yang belum menyentuh pada aspek kerja sama konkrit, terencana dan massif.

f. Ekonomi global yang fluktuatif akibat hancurnya ekonomi Negara adi kuasa (Amerika Serikat) sangat berpengaruh terhadap pengembangan ekonomi dunia. Secara langsung atau tidak langsung mempengaruhi pertumbuhan ekonomi mikro dan makro sebuah negara. Bahkan berdampak pada aspek-aspek non ekonomi, khususnya politik.

g. Sedikit para inisiator (promotor) dari umat Islam yang membuka akses kepada para investor dari Timur Tengah yang memiliki dana yang melimpah. Banyaknya kekayaan wakaf yang dimiliki oleh umat Islam Indonesia seharusnya menjadi daya tarik untuk pengembangan secara lebih produktif dengan melibatkan para investor asing yang memiliki perhatian terhadap pengembangan wakaf.

Jadi setidaknya ada 7 (tujuh) problematika yang dihadapi dalam mengimplementasikan wakaf di Indonesia, mulai dari pertentangan tentang pemahaman wakaf sampai pada kurangnya inisiator dari umat Islam untuk mengembangkan wakaf produktif tersebut.

Secara konseptual, wakaf uang mempunyai peluang yang unik untuk menciptakan investasi di bidang keagamaan, pendidikan, dan layanan sosial. Tabungan dari masyarakat yang mempunyai penghasilan menengah ke atas dapat dimanfaatkan melalui penukaran dengan Sertifikat Wakaf Uang (SWT), sedangkan pendapatan yang diperoleh dari pengelolaan wakaf uang dapat dibelanjakan untuk berbagai tujuan, di antaranya untuk pemeliharaan dan pengelolaan tanah wakaf.

Mustofa Edwin Nasution memaparkan cara memanfaatkan potensi SWT yang digali di Indonesia, yakni (Mustafa Edwin Nasution, 2006:5):

a. Lingkup sasaran pemberi wakaf uang bisa menjadi sangat luas dibanding wakaf biasa.

b. Sertifikat wakaf uang dapat dibuat berbagai macam pecahan, yang disesuaikan dengan segmen umat Islam yang memungkinkan untuk membangkitkan semangat beramal 
jariyah, misalnya Rp. 10.000,- dan Rp. 25.000,- Mustafa Edwin Nasution pernah melakukan asumsi bahwa jumlah penduduk Muslim kelas menengah di Indonesia sebanyak 10 juta jiwa dengan rata-rata penghasilan perbulan antara Rp 500.000,00 (lima ratus ribu rupiah) - Rp 10.000.000,00 (sepuluh juta rupiah) maka dapat dibuat perhitungan sebagai berikut(Mustafa Edwin Nasution, 2006:5).

Tabel 1: Potensi Wakaf Uang di Indonesia

\begin{tabular}{|l|l|l|l|l|}
\hline $\begin{array}{l}\text { Tingkat Penghasilan / } \\
\text { bulan }\end{array}$ & $\begin{array}{l}\text { Jumlah } \\
\text { Muslim }\end{array}$ & $\begin{array}{l}\text { Tarif } \\
\text { Wakaf/bulan }\end{array}$ & $\begin{array}{l}\text { Potensi Wakaf } \\
\text { Uang / bulan }\end{array}$ & $\begin{array}{l}\text { Potensi Wakaf } \\
\text { Uang / tahun }\end{array}$ \\
\hline$R_{P} 500.000$ & 4 juta & $R_{P} 5000,-$ & $R_{P} 20$ Milyar & $R_{P} 240$ Milyar \\
\hline$R_{P} 1$ juta - $R_{P} 2$ juta & 3 juta & $R_{P} 10.000$ & $R_{P} 30$ Milyar & $R_{P} 360$ Milyar \\
\hline$R_{P} 2$ juta - $R_{P} 5$ juta & 2 juta & $R_{P} 50.000$ & $R_{P} 100$ Milyar & $R_{P} 1,2$ Triliun \\
\hline$R_{P} 5$ juta- $R_{P} 10$ juta & 1 juta & $R_{P} 100.000$ & $R_{P} 100$ Milyar & $R_{P} 1,2$ Triliun \\
\hline Total & & & & $R_{P} 3$ Triliun \\
\hline
\end{tabular}

Adapun penjelasan dari tabel di atas adalah:

a. Apabila umat Islam yang berpenghasilan Rp. 500.000,00 sejumlah 4 juta orang dan setiap tahun masing-masing berwakaf sebanyak Rp. 60.000,00 maka setiap tahun terkumpul Rp. 240.000.000.000,00.

b. Apabila umat yang berpenghasilan Rp. 1.000.000,00 - Rp. 2.000.000,00 sejumlah 3 juta orang dan setiap tahun masing-masing berwakaf Rp. 120.000,00 maka setiap tahun terkumpul dana sebanyak Rp. 360.000.000.000,00.

c. Apabila umat yang berpenghasilan Rp. 2.000.000,00 - Rp. 5.000.000,00 sejumlah 2 juta orang dan setiap tahun masing-masing berwakaf Rp. 600.000,00 maka setiap tahun terkumpul dana sebanyak Rp. 1.200.000.000.000,00.

d. Apabila ummat yang berpenghasilan Rp. 5.000.000,00 - Rp. 10.000.000,00 sejumlah 1 juta orang dan setiap tahun masing-masing berwakaf Rp. 1.200.000,00 maka setiap tahun terkumpul dana sebanyak Rp. 1.200.000.000.000,00.

Dengan demikian wakaf yang terkumpul selama satu tahun sejumlah $\mathrm{Rp}$. 3.000.000.000.000,00. Berdasarkan contoh perhitungan di atas maka terlihat bahwa 
keberhasilan lembaga untuk memobilisasi dana wakaf akan sangat menentukan manfaat keberadaan lembaga wakaf, yang menjadi masalah, uang tersebut tidak dapat langsung diberikan kepada mauquf 'alaih, tetapi nadzir harus mengelola dan mengembangkannya terlebih dahulu. Yang harus disampaikan kepada mauquf 'alaihadalah hasil investasi dana Rp. 3.000.000.000.000,00 tersebut, sedangkan uang wakafnya sendiri tidak boleh berkurang sedikit pun.

Hal ini jika dapat diimplementasikan maka akan berpengaruh signifikan terhadap peningkatan kesejahteraan masyarakat. Program-program pemerintah berkaitan dengan pengembangan ekonomi masyarakat merupakan suatu problematika yang sudah ada sejak dulu hingga sekarang dan tidak pernah terlepas dari hal tersebut.Untuk itu dengan analisis sebagaimana uraian di atas merupakan salah satu faktor yang dapat dijadikan sebagai program pemerintah dalam meningkatkan kesejahteraan masyarakat.

\section{IMPLEMENTASI WAKAF PRODUKTIF}

Oleh karena Nazhir mempunyai peranan penting dalam mengelola harta wakaf agar sesuai dengan apa yang diinginkan oleh wakif dan bisa dirasakan manfaatnya oleh masyarakat maka Nazhir harus mempunyai program-program kerja baik program jangka pendek maupun program jangka panjang.

\section{PROGRAM JANGKA PENDEK}

Dalam rangka mengembangkan wakaf secara produktif, maka pemerintah membentuk badan wakaf Indonesia (BWI) yang mempunyai tujuan untuk menyelenggarakan koordinasi dengan Nazhir dan pembinaan manegemen wakaf secara nasional dan internasional.Pembuatan BWI itu sesuai dengan UU No 41 tahun 2004 tentang wakaf pasal 47 sampai pasal 161. Adapun tugas- tugas BWI (Badan Wakaf Indonesia) sebagai berikut:

a. Melakukan pembinaan terhadap Nazhir dalam mengelola dan mengembangkan harta benda wakaf.

b. Melakukan pengelolaan dan pengembangan harta benda wakaf bersekala nasional dan internasioanal. 
c. Memberikan persetujuan dan atau izin atas perubahan peruntukan dan status benda wakaf.

d. Memberhentikan dan mengganti Nazhir.

e. Memberikan persetujuan atas penukaran harta benda wakaf.

f. Memberikan saran dan pertimbangan kepada pemerintah dalam penyusunan kebijakan dibidangperwakafan (UU No. 41 Tahun 2004).

Dengan adanya tugas- tugas diatas maka BWI Harus diisi oleh sumberdaya manusia yang berkualitas agar harta wakaf bisa bermanfaat bagi seluruh umat manusia dan berguna juga mengentaskan kemiskinan yang selama ini menjadi fenomena yang belum bisa dituntaskan oleh pemerintah.

\section{PROGRAM JANGKA MENENGAH DAN PANJANG}

Mengembangkan lembaga-lembaga Nazhir yang sudah ada agar lebih kredibel (professional dan amanah) maka lembaga-lembaga tersebut harus diarahkan, dibina dan diberikan stimulus (rangsangan) agar harta wakaf tersebut dapat dikembangkan secara produktif. Dengan demikian lembaga- lembaga tersebut berjalan sesuai dengan rencana maka harus didukung oleh beberapa hal sebagai berikut:

a. Dukungan SDM Nazhir

Nazhir dalam wakaf merupakan sentral dalam pengelolaan wakaf, maka eksistensi dan kualitas SDM-nya harus betul- betul diperhatikan. Agar kualitasnya benar- bennar terwujud maka seorang Nazhir harus mempunyai syarat- syarat seperti diatas dengan melihat aspek- aspek sebagai berikut:

1) Transparansi, Transparansi adalah aspek penting yang tak terpisah dalam rangkaian kepemimpinan yang diajarkan oleh nilai- nilai Islam. Transparansi merupakan ciri utama yang harus ada dalam kepemimpinan, agar tidak ada tindakansewenangwenang.

2) Publikaccountability (pertangungjawaban).

3) Aspiratif (mau mendengar dan mengakomodisi seluruh dinamika lembaga kenazhiran). 
b. Dukungan advokasi

Pembentukan advokasi bisa dilakukan oleh lembaga nazhir yang besangkutan dengan bekerjasamawakaf Indonesia (BWI) sebagai pihak pengayom dan Pembina secara kelembagaan.Advokasi berguna agar tanah yang sudah diwakaf tidak bisa diambil alih oleh orang- orang yang sengaja ingin memiliki harta wakaf tersebut kerana melihat ada potensi yang terdapat dalam wakaf tersebut untuk kepentingannya sendiri.

c. Dukungan keuangan

Upaya pengembangan wakaf produktif sangat bergantung pada dukungan keuangan yang memadai guna membiayai seluruh operasional pengelolaan wakaf.Dukungan keuangan ini bisa dilakukan melalui lembaga keuangan terkait khususnya lambang perbankan syari'ah dengan cara bagi hasil.

d. Dukungan pengawasan

Dukungan ini diperlukan agar tidak terjadi penukaran harta wakaf dan juga agar nazhir yang berhadapan langsung dengan harta wakaf dapat menjalankan tugasnya dengan baik dan benar sehingga mendapatkan keuntungan yang memadai.Pengawasan ini meliputi manegeman organisasi, menejeman keuangan dan menejemen pelaporan kepeda pihak atau lembaga yang lebih tinggi (WaidyFarid dan Musyid, 2000:86).

Sebagaimana uraian di atas maka terlihat pentingnya pemberdayaan wakaf produktif dalam upaya menciptakan masyarakat yang sejahtera. Dengan program-program yang dibuat baik dalam jangka pendek maupun jangka panjang akan memberikan gambaran perencanaan dan pelaksanaan yang sistematis yang tujuan akhirnya adalah meningkatkan taraf hidup masyarakat.

\section{PERAN WAKAF DALAM PEMBERDAYAAN EKONOMI UMAT}

Tidak dapat dipungkiri bahwa wakaf adalah sebagai salah satu tambahan pemasukan baru. Hal ini akan menyebabkan adanya peningkatan pada permintaan terhadap barang. Sedangkan pada sektor produksi akan menyebabkan bertambahnya produktivitas, sehingga 
perusahaan-perusahaan yang telah ada semakin bergerak maju, bahkan memunculkan berdirinya perusahaan-perusahaan baru untuk menghadapi permintaan tersebut. Di lain pihak, modal yang masuk ke perusahaan tersebut semakin bertambah banyak. Setiap suatu barang sangat penting dan merupakan kebutuhan yang mendasar, setiap itu pula permintaan tidak akanberubah. Hal inilah yang menyebabkan terus-menerusnya produktivitas perusahaan dan terjaminnya modal-modal yang diinvestasikan.

Timbulnya peningkatan pada permintaan dapat dibuktikan ketika harta wakaf dibagikan kepada mereka yang berhak menerimanya. Dan peningkatan pembelian tersebut tidak akan terjadi kecuali dengan adanya penambahan pemasukan, salah satunya adalah wakaf.

Ketika wakaf diambil dan dikumpulkan dari mereka yang memiliki pemasukan tinggi dan diberikan kepada mereka yang memiliki pemasukan terbatas, maka kecondongan konsumtif dari mereka yang memiliki pemasukan yang tinggi akan lebih sedikit dari mereka yang memiliki penghasilan terbatas. Pengaruh optimis wakaf adalah pengecualian dari tingkat perbedaan antara kecondongan konsumtif dengan pemasukan yang ada untuk mewujudkan keseimbangan antara pengeluaran dan pemasukan. Dengan arti bahwa kecondongan konsumtif akan menjadi semakin besar ketika wakaf telah dilaksanakan dibandingkan dengan sebelumnya.

Ada beberapa pendayagunaan atau pemberdayaan wakaf produktif di antaranya adalah sebagai berikut:

a. Orientasi pembangunan wakaf diberikan tidak sekedar sampai pada pihak tertentu, akan tetapi kiranyawakaf dapat bermanfaat sebagai kepentingan umum. Adapun apa yangdiwakafkan untuk diproduksikan, apabila diganti dengan yang lebih baik, seperti wakaf rumah, kedai, kebun atau kampongyang produksinya kecil,maka ia diganti dengan apa yang lebih bermanfaat bagi wakaf itu.

b. Benda wakaf yang lazim selama ini adalah benda wakaf tidak bergerak, khususnya tanah milik. Namun karena perkembangan ekonomi yang pesat, maka orang yang akan berwakaf (wakif) semakin berkembang, mereka mewakafkan benda-benda selain tanah 
juga berupa benda bergerak seperti: uang chas, saham atau surat berharga lainnya dapat juga berupa mobil, motor, perahu dan berbagai jenis barang lainnya.

Namun untuk mengatasi agar benda dapat terjaga dengan baik agar dapat dikelolah secara optimal kemudian dapat menjadikannya sebagai wakaf yang produktif.Di samping itu penanganan proyek tentu sudah dilakukan pula lembaga-lembaga sosial lainnya. Dana yang dikumpulkan dapat dimanfaatkan untuk meningkatkan kesejahteraan lahir batin masyarakat, meliputi:

\section{BIDANG SARANA IBADAH}

a. Membantu membangun/merehabilitasi mesjid, langgar dan musholla.

b. Menggairahkan dan membantu perlengkapan kegiatan ibadah wajib lainnya.

\section{BIDANG PENDIDIKAN}

a. Mendirikan dan atau membantu pembangunan/rehabilitasi madrasah dan pondok pesantren terpadu.

b. Pembangunan prasarana dan sarana keterampilan.

c. Meningkatkan dakwah.

d. Penelitian Islam.

e. Publikasi mengenai Islam baik yang bersifat akademis maupun yang bersifat ilmiah populer.

f. Mendirikan perpustakaan Islam dan membantu perpustakaan Islam yang ada.

\section{BIDANG KESEHATAN}
a. Mendirikan rumah sakit Islam.
b. Mendirikan Puskesmas.
c. Mendirikan rumah-rumah bersalin. 


\section{BIDANG PELAYANAN SOSIAL}

a. Mendirikan rumah-rumah yatim piatu.

b. Mendirikan rumah orang tua jompo.

c. Mendirikan rumah penderita cacat.

d. Membantu rumah-rumah yatim piatu, orang tua jompo dan penderita cacat.

\section{BIDANG EKONOMI}

a. Menyediakan lapangan kerja bagi fakir miskin sesuai keahlian dan kemampuannya.

b. Memberikan pendidikan dan latihan keterampilan kepada remaja drop out.

c. Memberikan modal kerja dan sarana bekerja bagi fakir miskin dan remaja drop out.

d. Mengembangkan usaha pertanian, perkebunan, perikanan dan kerajinan bagi petani, nelayan dan pengrajin miskin.

e. Membantu persiapan dan pelaksanaan transmigrasi.

f. Mendirikan pusat studi Islam (Pustudis).

g. Mendirikan musium peninggalan budaya Islam.

h. Memberikan dana bantuan kepada lembaga-lembaga keagamaan yang bergerak di bidang pendidikan, dakwah, kesehatan, pelayanan sosial, tempat ibadah dan lain-lain.

\section{STRATEGI PENGEMBANGAN WAKAF PRODUKTIF}

Untuk mengimplementasikan wakaf produktif maka diperlukan suatu strategi yang dapat mengembangkannya. Sebagaimana menurut Eddy Khairani, ada beberapa hal yang perlu dilakukan untuk strategi pengembangan wakafproduktif, yaitu:

a. Regulasi peraturan perundang-undangan wakaf;Ditjen Bimas Islam terus melakukan regulasi di bidang peraturan perundang-undangan wakaf. Setelah lahirnya UndangUndangNomor: 41 tahun2004 tentangWakaf dan Peraturan Pemerintah Nomor 42 Tahun 2006 tentang Pelaksanaan UU No. 41 Tahun 2004 tentang Wakaf, saat ini sedang disusun Draft Peraturan Menteri Agama tentang Petunjuk Pelaksanaan Wakaf di Indonesia. Dengan PMA tersebut diharapkan praktik wakaf dapat berjalan sebagaimana mestinya untuk kepentingan kesejahteraan umum. 
b. Sosialisasi peraturan per-UU wakaf dan paradigma baru wakaf;Dalam rangka untuk memasyarakatkan peraturan perundang-undangan wakaf dan paradigma baru wakaf di Indonesia, Ditjen Bimas Islam melakukan sosialisasi melalui berbagai event lokal maupun nasional, seperti: (1) Lokakarya perwakafan masyarakat kampus; (2) Sosialiasi Wakaf Tunai di lingkungan BMT dan LKS; (3) Training manejemen pengelolaan wakaf di lingkungan Nazhir, dan lain-lain. Sosialisasi tersebut dilakukan bertujuan menginformasikan kepada masyarakat pada umumnya, dan kepada para aparat Negara yang terkait dengan pengelolaan wakaf di Indonesia, sekaligus menjadikan media massa sebagai mitra pemerintah dalam upaya pemberdayaan wakaf.

c. Sertifikasi, inventarisasi, dan advokasi harta benda wakaf;Untuk menjalankan amanat Undang-Undang Nomor 41 tahun 2004 tentang Wakaf terkait dengan pengamanan harta benda wakaf di Indonesia, Ditjen Bimas Islam menetapkan berbagai kebijakan, yaitu:

1) Menyelesaikan proses sertifikasi terhadap tanah-tanah wakaf di berbagai daerah yang belum memiliki sertifkat wakaf. Sertifikasi terhadap tanah wakaf merupakan langkah pengamanan asset-aset wakaf di Indonesia secara hukum dari berbagai kepentingan di luar wakaf.

2) Inventarisasi harta benda wakaf di seluruh Indonesia melalui sistem komputerisasi.

3) Melakukan pemetaan potensi harta benda wakaf, sehingga dapat diketahui potensi yang dapat dikembangkan.

4) Melakukan advokasi, perlindungan dan penyelesaian sengketa tanah wakaf dengan pihak-pihak ketiga.

d. Peningkatan kualitas Nazhir dan lembaga wakaf;Nazhir dan lembaga pengelola wakaf sebagai ujung tombak pengelolaan dan pengembangan harta benda wakaf diberikan motivasi dan pembinaan dalam rangka meningkatkan profesionalisme manajemen, melalui berbagai pelatihan dan orientasi. Kualitas Nazhir di Indonesia terus diberikan motivasi dan arahan dalam rangka melakukan pembenahan, baik menyangkut kemampuan manajerial maupun skill individu yang sangat menentukan dalam pemberdayaan wakaf secara produktif. 
e. Menfasilitasi jalinan kemitraan investasi wakaf produktif;Sebagai motivator dan fasilitator, Ditjen Bimas Islam memfasilitasi di berbagai event dalam rangka untuk menggalang kemitraan usaha dengan para calon investor seperti Badan Koordinasi Penanaman Modal (BKPM) dan Kamar Dagang dan Industri (KADIN) di beberapa daerah dalam pemberdayaan wakaf secara produktif. Aset-aset wakaf di Indonesia yang cukup besar sangat potensial untuk dikembangkan dengan mengajak beberapa lembaga pihak ketiga yang tertarik dalam pengembangan wakaf.

f. Memfasilitasi terbentuknya Badan Wakaf Indonesia (BWI); Dalam rangka untuk mendukung pengelolaan dan pengembangan wakaf di Indonesia, Ditjen Bimas Islam memfasilitasi terbentuknya Badan Wakaf Indonesia (BWI) sebagai lembaga yang memiliki tugas, diantaranya pembinaan terhadap Nazhir di seluruh Indonesia (Eddy Khairani, 2013:39).

Jadi ada 6 (enam) strategi yang dapat dikembangkan untuk memberdayakan wakaf produktif ini, mulai dari produk hukumnya sampai pada membangun jaringan dalam bentuk kemitraan investasi produktif.Salah satunya adalah wakaf uang yang dapat membuka peluang yang unik untuk menciptakan investasi guna memberikan pelayanan keagamaan, layanan pendidikan, dan layanan sosial.Tabungan orang-orang kaya dapat dimanfaatkan dengan menukarkannya dengan Cash-Waqf Certificate.Hasil pengembangan wakaf yang diperoleh dari sertifikat tersebut dapat dimanfaatkan untuk tujuan-tujuan yang bermacam-macam seperti tujuan-tujuan wakaf itu sendiri. Kegunaan lain dari Cash Waqf Certificate adalah bahwa dia dapat mengubah kebiasaan lama di mana kesempatan wakaf seolah-olah hanya untuk orang-orang kaya saja.

\section{KESIMPULAN}

Jadi ada 6 (enam) strategi yang dapat dikembangkan untuk memberdayakan zakat produktif ini, mulai dari produk hukumnya sampai pada membangun jaringan dalam bentuk kemitraan investasi produktif.Salah satunya adalah wakaf uang yang dapat membuka peluang yang unik untuk menciptakan investasi guna memberikan pelayanan keagamaan, layanan pendidikan, dan layanan sosial.Nazhir mempunyai peranan penting dalam mengelola harta 
wakaf agar sesuai dengan apa yang diinginkan oleh wakif dan bisa dirasakan manfaatnya oleh masyarakat maka Nazhir harus mempunyai program-program kerja baik program jangka pendek maupun program jangka panjang.Dalam rangka mengembangkan wakaf secara produktif, maka pemerintah membentuk badan wakaf Indonesia (BWI) yang mempunyai tujuan untuk menyelenggarakan koordinasi dengan Nazhir dan pembinaan manegemen wakaf secara nasional dan internasional.Program jangka menengah dan panjang yaitu mengembangkan lembaga-lembaga Nazhir yang sudah ada agar lebih kredibel (professional dan amanah) maka lembaga-lembaga tersebut harus diarahkan, dibina dan diberikan stimulus(rangsangan) agar harta wakaf tersebut dapat dikembangkan secara produktif.

\section{DAFTAR PUSTAKA}

AdiwarmanAzwar Karim, (2004). Sejarah Pemikiran Ekonomi Islam.Jakarta: PT. Raja Grafindo Persada.

Aziz, Hamka Abdul, (2012). Pemberdayaan Wakaf Produktif. Jakarta: Al-Mawardi Prima.

Badan Pusat Statistik (BPS), (2017). Profil Ekonomi di Indonesia. Jakarta: BPS.

Direktorat Pemberdayaan Wakaf dan Direktorat Jenderal Bimbingan Masyarakat Islam, (2008).Wakaf.Jakarta: Kementerian Agama RI.

Eddy Khairani, (2013). Strategi Pengembangan Wakaf Produktif.Jogyakarta: CV. Cahaya Islam.

Eddy Khairani, (2013). Strategi Pengembangan Wakaf Produktif.Yogyakarta: Cahaya Iman.

Kementerian Agama RI., (2012). Al-Qur'an dan Terjemahnya. Jakarta: Yayasan Penyelenggara Penterjemah.

M. Ali Hasan, (2003). MasailFiqhiyah.Jakarta: PT Raja Grafindo Persada.

M. Anwar Musaddad,(2014). Wakaf Produktif http://www.wakafcenter.org. Diakses Sabtu, 19 September 2017.

M.IchsanAmirMujahid, (2012). StrategiNazhirDalamPengembanganWakaf Produktif,http://k2ichsan.blogspot.com/2012/06/strateg, Diakses tanggal 03 Februari 2017.

Mustafa Edwin Nasution, (2006). Pengenalan Eksklusif Ekonomi Islam.Cet. I; Jakarta: Kencana Prenada Media Group.

Redaksi Tamita Utama, (2008). UUD 45 dan Amandemen I-IV.Jakarta: CV. Tamita Utama. UU No 41 tahun 2004 tentang wakaf.

WaidyFarid dan Musyid, (2000)..Perspektif Wakaf di Indonesia. Yogyakarta: Cahaya Iman. 